\title{
1915年巴奈馬太平洋万国博日本館の建築意匠について THE DESIGN OF THE JAPANESE PAVILION AT PANAMA-PACIFIC INTERNATIONAL EXPOSITION IN SAN FRANCISCO, 1915
}

\author{
三島 雅博* \\ Masahiro MISHIMA
}

\begin{abstract}
Japanese Government erected its pavilion at Panama-Pacific International Exposition in San Francisco in 1915. This pavilion was modeled on Kinkaku-ji temple and designed by Goichi Takeda. He used historically different ornaments compared to the the original model. It was a new design arrangement, but his design attitude was positive that we have never seen before. In this work, we can see a new intension to create a new Japanese architecture style. This pavilion was also modeled on famous Japanese historical buildings like the precedents did in Meiji-era. However, after the international exposition, Japanese pavilion like this one has never been erected. This pavilion can be the compilation of the Japanese pavilion of Meiji-era.

Takeda designed some temples based on historical styles with new arrangement after this pavilion. This pavilion can be a study model of temples that he designed.
\end{abstract}

Keywords : Japanese pavilion, Goichi Takeda, exposition, Japanese style

\section{1.はじめに}

第一次世界大戦中の大正 4 年 (1915)、米国サンフランシスコに 於いてパナマ運河の開通を記念する巴奈馬太平洋万国博覧会 (以下 「パナマ万博」とする)が開催された"1)。これに日本政府は参同し、 伝統的日本建築 (以下「日本建築」と記す)の形態を持つ日本館を 建設したが、それが武田五一の設計によるものであることや金閣寺 をモデルとしたこと、また金閣寺をモデルとしながらも、それとは 里なる時代の意匠を用いたことなどが知られている。

管見によれば、これまでの研究でパナマ万博の日本館を报ったも のとしては黒川直樹氏によるものがあるが2、、れは建設されたア メリカでの評価を中心に考察されており、日本館の建物そのものの 内容について詳しく触れられてはいない。また藤岡洋保・樑谷康生 の両氏による研究の中でもこの建物について触れられている ${ }^{3 !}$ 。両 氏は、戦前の万国博日本館の設計で複数の様式を混在させること は、新しい和風建築をつくってみせるという発想に基づいたもので あるとされており、その積極的な姿勢が現れた例として、これを挙 げられている。しかし、そのような混在はパナマ万博以前から行お れており、両氏の研究では、そのような発想が形成されてゆく過程 などには触れられていない。さらにこの点で、欧米の新建築の導入 や近代和風建築の進展に大きな貢献を果たした武田五一がこの万博 の日本館の設計者であったことは重要である。 本稿は、その形態の考察を通して、それが万国博日本館の変遷の
中で占める位置や、その設計態度の考察により、武田五一を通して 当時の日本人建築家の「日本建築」に対する意識の一端を明らかに しょうとするものである。

なお基本資料としては、本万博終了後に農商務省により発行され た報告書 ${ }^{4)}($ 以下『報告書』と記す)や、さらに当時日米で発行さ れた雑誌、記念誌などを用いた。

\section{2. 日本館建设まての経䋖}

日本政府がパナマ万博開催を米国政府から正式に通知されるのは 明治 45 年 (1912) 2 月 6 日のことである。同日「国務卿フキラン ダー、シー、ノックス」は米国駐在埴原大使代理にパナマ万博開催 の大統領宣言書を送付するとともに日本政苻の参同を要請した。こ れを受け日本政府は、同年 4 月 30 日の閣議を経て翌 5 月 1 日には 外務大臣を通して日本駐在の米国大使に対して、参同することを通 告した ${ }^{5)}$ 。

注目されるのは、この時から始められる日本政府の参同準備の 内容と人選である。日本政府は参同通告後まもなく準備委員 3 名を 任命して参同事業を正式に始めるが、この中に武田五一が入ってい た。初期の準備段階から建築の専門家が入っていたことは、これま での万国博参同事業には汪とんど見られなかったことであった ${ }^{6)}$ 。 武田は同年 6 月 25 日に農商務省加「巴奈馬太平洋万国博覧会事 務取报噧託」を命じられてお、、、準備委員長であった山脇春樹、同

本稿は，1999年日本建築学会大会で発表した「巴奈馬太平洋万国博の日本館について」をもとに，その後の知見を加之て量き改めたものである。

* 豊田工業高等専門学校建築学科 助教授·博士(工学) Assoc. Prof., Dept. of Architecture, Toyota National College of Technology, Dr. Eng. 


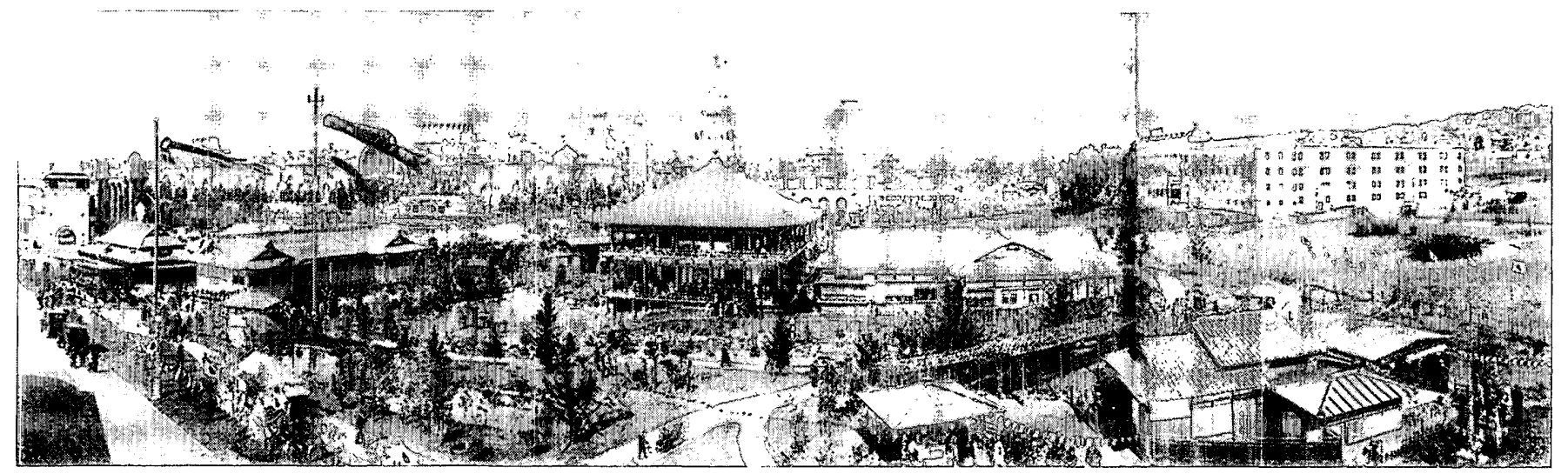

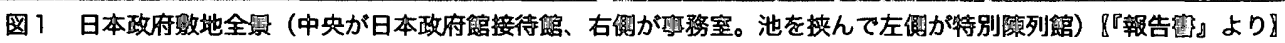

じく準備委員である農商務省参事官片山義勝とともに、すでに決定 していた参同方針を訓示された上で 7 月 28 日にアメリカに準備調 㚗のため派遗された。

その参同方針であるが、第一にあげられたのが「特別館」の建設 であった。建築面積 300 坪程度で、建設の第一の目的を接待に置き、 他にも政府出品の一部を展示できることとしている。また、政府館 及び庭園の敷地として 5000 坪程度の広さのもの一ヶ所を選定する こと、(別な敷地であるにせよ) 特別な出品のために建物を建設す る際には日本側事務局の認可を得ること、喫茶店は日本庭園内に建 設する予定で交涉すること、などが建築関係の参同方針として事前 に準備委員に伝えられていた 。

この方針を基に準備委員に指示された米国に扮ける様々な調㚗事 項にも、他国のパビリオン建設に関する情報の収集や、日本館建設 に関しての具体的な状況や費用に関する調査など、建笁に関するも のが多く含まれていた。

以上のように、日本政府は当初から日本館建設に意欲的な方針を 取り、調㚗を行っていた。従って、この日本館は積極的な準備態劫 が取られたうえで建設されたものであることが分かる。

また、多くの建築関係の事項を理解し調㚗することが準備委員に 望まれていたのであるから、そこに武田という建築の専門家が入れ られたのは当然のことであった。

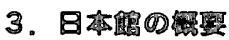

日本館に与えられた敷地は 145,500 平方7イート(約 4000 坪) あり、 緩やかな傾斜があるものであった。それを日本式の塀で囲んだうえ で、門を設け、池を穿つなどの日本式の造園を施した。そして日本 政府館、正門、特別陳列館、日本喫茶店、茶室及び附属休䀣所, 物 㯰，四阿、台湀喫茶店及び附属四阿、さらに出品者でもあった横浜 植木会社の小さな事務所などが建てられた。

これらの中の最も巨大で、かつ、その形態の点からも注目される のが日本政府館であり、日本政府が参同方針を示した段階で挙げて いた「特別館」がこれに相当し、中心的建物であった ${ }^{8)}$ 。これは武 田五一の設計になるもので、接待館と事務室からなり、全体の面積 は218.75 坪、そのうち接待館が 100 坪、事務室が 116.25 坪、渡 廊下が 2.5 坪であった。

接待館は 11 間四方の正方形平面、軒高 30 尺で方形屋根を持ち、 頂部には鳳凰を載せ、そこまでの高さは 58 尺であった。外見上は
2 層の建物であるが、内部中心部は 2 階まで吹抜けており、建物全 体としては 1 室で、そこが接待室となっていた。その周囲は、1階 2 階ともに同幅の縁が設けられ、2 階へは緑内に設けられた階段よ り上がるようになっており、そこからは周囲の庭園やさらに 2 階か らは周囲の外国館といった景色を見渡せるようになっていたが、こ れは武田が述べるところによると、太平洋岸の住宅に見られる「べ

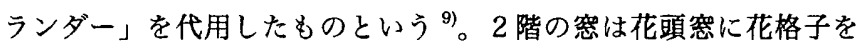
組み込んだもの、1 階は格子空で、出入り口は栈唐戸としている。 接待室の内装であるが、寄木張りの床、二重折上格天井、金䈃の張

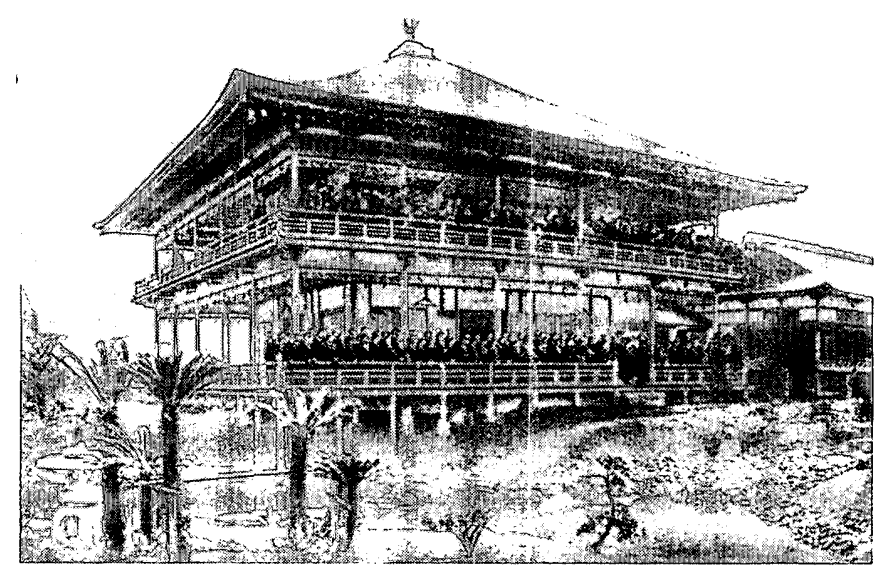

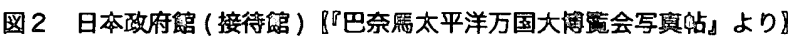

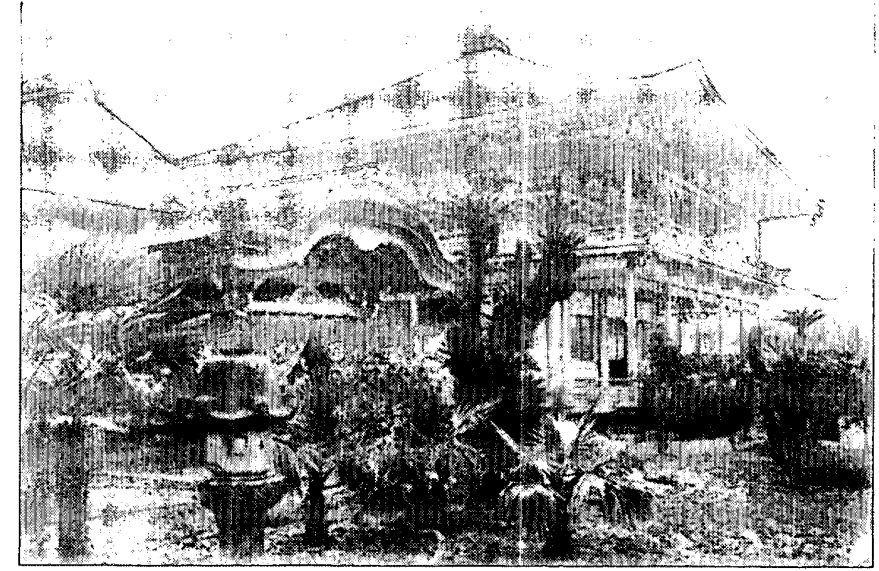

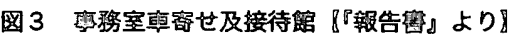




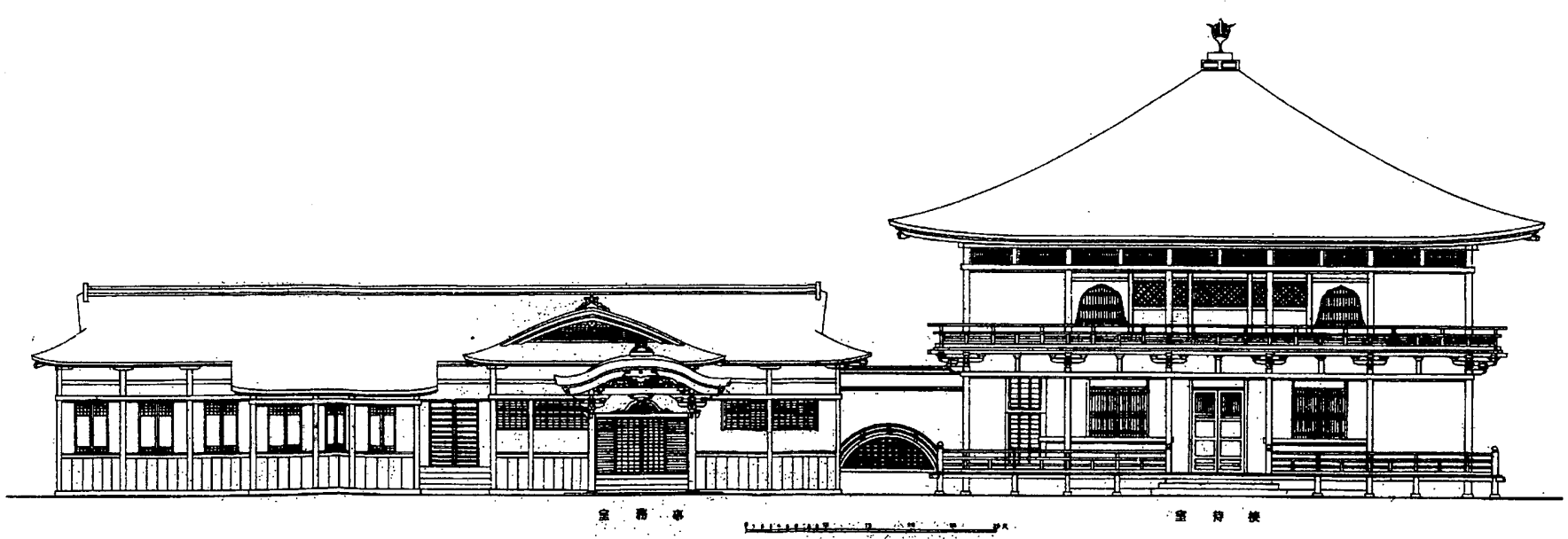

図4 日本政府館立面 [『報告費』より】

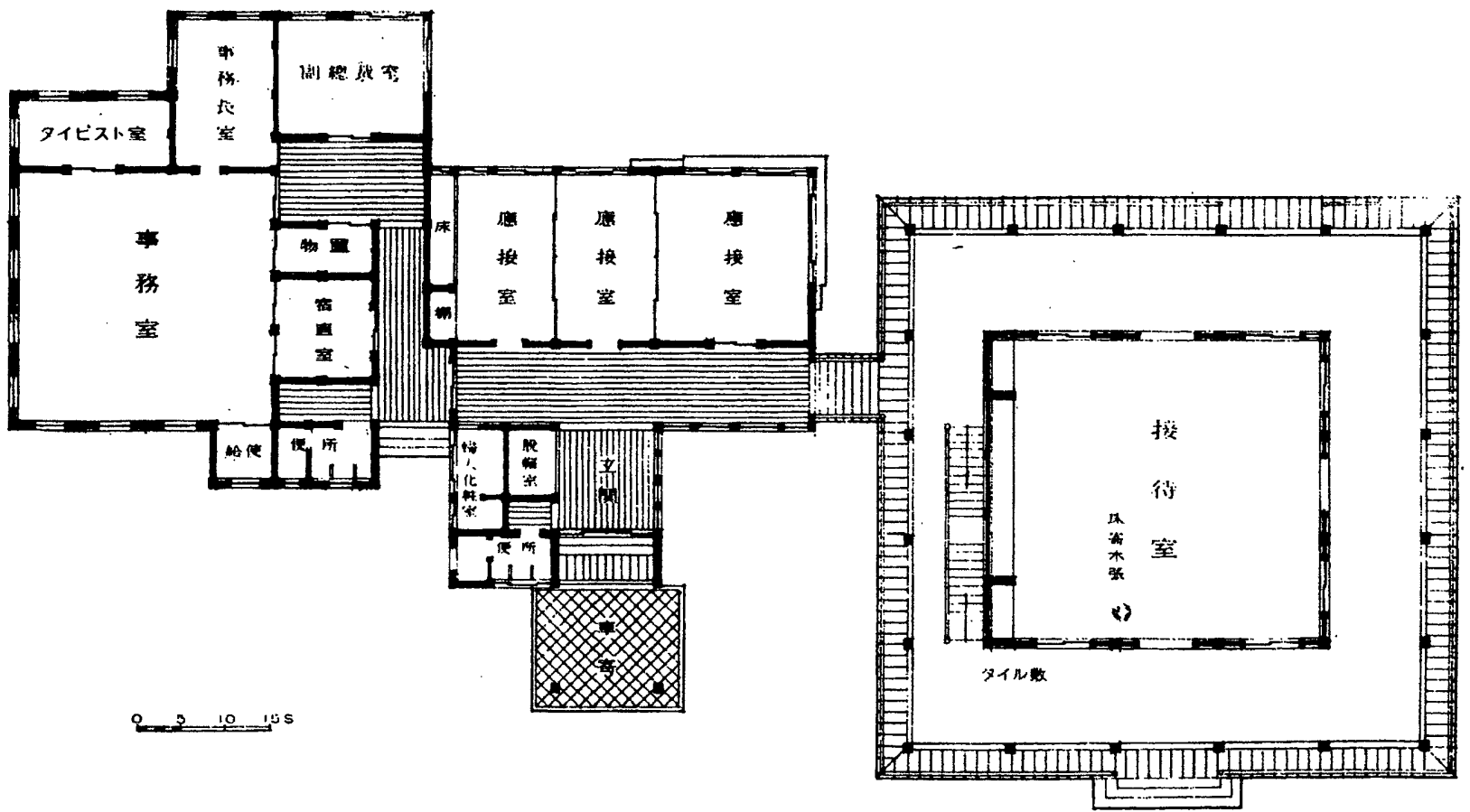

図 5 日本政府館平面【『武田博士作品集』武田博士還暦記念较業会、昭和 8 年 より】

り付け壁、南側壁には中央に床，その左右に違棚を備えていた。

『報告書』では日本政府館のデザインについて、接待館と事務室 の車寄せに特に力を入れたとしている。そして、鹿苑寺金閣をモデ ルとしながらも細部にはす新手法」を加え、また、装飾彫刻の意匠 は鎌倉末期より豊臣初期の実例を参照したとしている。その記述を 精読すると、金閣をモデルとしたのが接待館であり ${ }^{10}$ 、鎌倉末期 から豊臣初期の実例を参照したのが、事務室車寄せの唐破風造りを 指していると考えられる ${ }^{11)}$

これに加え、武田五一は日本館の建設を終えて㷌国した後に建築 学会で開かれた講演会で、接待館の蟇股に鎌倉時代の形式を使った こと、事務所は「簡単」なもので、車寄せだけを「立派」にしたこ とを述べている ${ }^{12)}$

武田は日本政府館以外にも、正門 (表門)を設計している。これ は平唐門形式で、鎌倉時代の様式を基に彫刻は事務室車寄せと同様 の「新手法」を用いたとしている ${ }^{13)}$
以上より、モデルとは異なる時代の意匠を混在させていたのは、 接待館や事務室車寄せ、正門 (表門) であったこと、事務室が車寄 せを除いて、モデルや時代表現を特別に意識した造形ではないこ そ、などが分かった。すなわち、武田がパナマ万博のために設計し た建物はいずれも、ある歷史様式を基にしながらも異なる時代意匠 を混在させた物であった。

なお、これら武田が設計した建物は京都市の本城清右衛門 ${ }^{14)}$ が 請け負い、京都で切組工事をしたのち船積みされ、サンフランシス コの現場で組み立てられた。

参同方針での「特別館」で構想されていた政府出品を陳列する 機能は日本政府館とは別の「特別陳列館」で実現した。その面積は 88 坪で、日本の敷地内の建物としては日本政府館に次いで大きい。 これも日本政府館同様に歴史的様式を用いており、『報告書」には 単に平安時代の様式を採用したと記されているが ${ }^{15}$ 、武田五一は 「藤原時代の御殿造」を基本として作られたものであると、より詳 

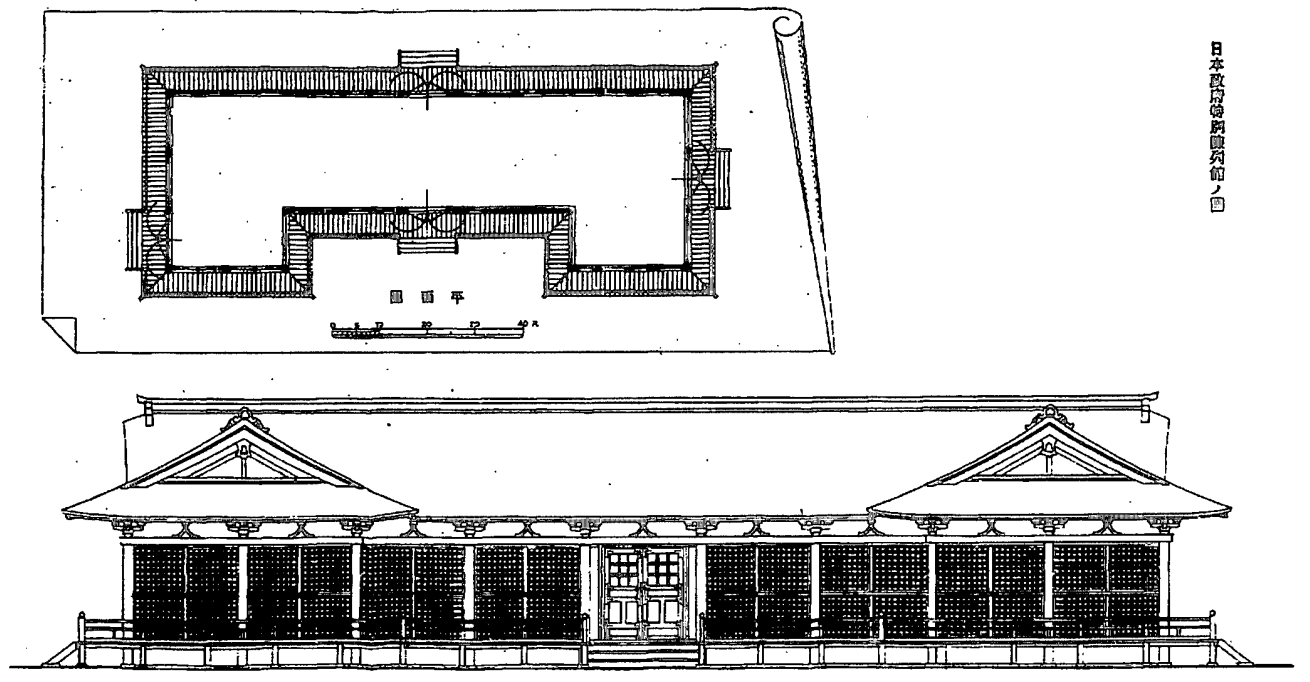

田 保四 II

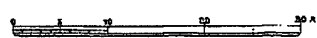

図 7 特別陳列館立面及び平面『『報告唒』より】
マ万博の日本館は、これらとは異な る造形意図を持っていたと言わざる を得ない。

これら以外にも注目されるのは、 欧州留学から掃国した直後の明治 36 年から 37 年にかけ、武田が鹿 苑寺金閣の修理工事に従事したこと である。この時の経験は武田がパナ マ万博の日本政府館を設計するにあ つたて充分に役立ったであろうこと は想像に難くない。

パナマ万博以後の作品としては、 まもなく畄州清水寺を大正 6 年から 12 年にかけて手がけているし、こ れ以外にも昭和 8 年の円教寺摩尼殿 をはじめとする大作があり、こうい つた「日本建筑」は武田の代表作の 一角を占めるものとなっている。
しく述べている ${ }^{16)}$ 。出入口以外の全ての開口部に部戸を用いてい る点などに、平安時代風の表現が試みられていることがわかるが、 左右に翼部を形成し破風を見せて正面性を強調するのは歴史様式に 忠実なものではない。

特別陳列館の設計者は『報告書』には記されていないが、武田で あった可能性が高い。というのも、先に挙げた㷌国後の講演会で、 武田は日本政府館や事務所の設計内容について説明した後に、この 建物について「藤原時代の御殿造を土台にして拔えた」と、自らの

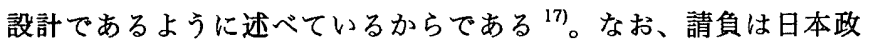
府館などとは異なり、東京市の戸田利兵衛であって、日本政府館の 場合と同様に日本で切り組みし、現地で組み立てた物であった。

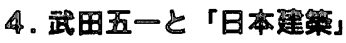

武田が設計者に選ばれた理由には、準備委員に任命されていたこ ともあるが、さらには日本建築に造詣が深かったことがあうう。こ れまでに立てられた万国博の日本館はいずれも「日本建築」の形態 を持っており、さらにそれらは先例を踏まえる傾向があったといわ れているから ${ }^{18)}$ 、この時の日本館建設に際しても設計者に求めら れたのは「日本建築」様式を报える能力であったと考えられる。

武田は三高時代にはすでに塚本靖との交流を通じ日本建築に興 味を持ち始めていたと考えられており ${ }^{19)}$ 、明治 30 年の東京帝国大 学卒業論文は「茶室の沿革」であった。また、パナマ万博以前にも 「日本建筑」の形態を用いた実作を幾つか手掛けている。妻不頼黄 の「助手」として衝いたものであるが、日本勧業銀行 (M32) があり、 伊東忠太に「協力」したもので台湾神社 (M32) があった ${ }^{20)}$ 。ただ、 それらの設計については妻木や伊東という主役が別におり、あくま で武田の名は脇役であった。さらに、日本勧業銀行は和洋折克の作

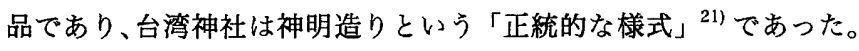
ところがパナマ万博の日本館は「日本建築」の形熊を用いたうえに、 複数の時代の意匠を加えると云う「新手法」を用いていたのである。 したがって、同じょうに「日本建築」の形態を用いながらも。パナ

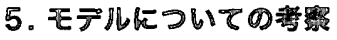

パナマ万博の日本館は、鹿苑寺金閣をモデルとして建設された最 初の日本館であったが、金閣そのものがモデルとして万国博の舞台 に登場したのはこれが最初ではない。

金閣寺のような歴史的建築物をモデルに採った日本館が建てられ たのは、明治 26 年 (1893) のシカゴ万博が最初であった。その時 の日本館はモデルを平等院鳳凰堂に採ったが、そのモデル候補には 金閣寺も挙げられていた ${ }^{22)}$ 。最終的には高さの問題などから鳳凰 堂がモデルに決定したが、検討段階ではむしろ金閣寺のほうが有力 であったと考えられるものであった。

ついで、万国博に金閣の名が登場するのは明治 37 年 (1904)の セントルイス万博である。「金閣」と名付けられた、日本茶の輸出 促進を目的とした契茶店がそれであるが、これは日本の茶業組合中 央会議所が建設した物であった。従って、日本政府は設計には直接 関わっておらず、建設の補助金を出資したうえで、設計の諗可をし ただけであるから、正式には日本館と呼べる物ではない。しかし、

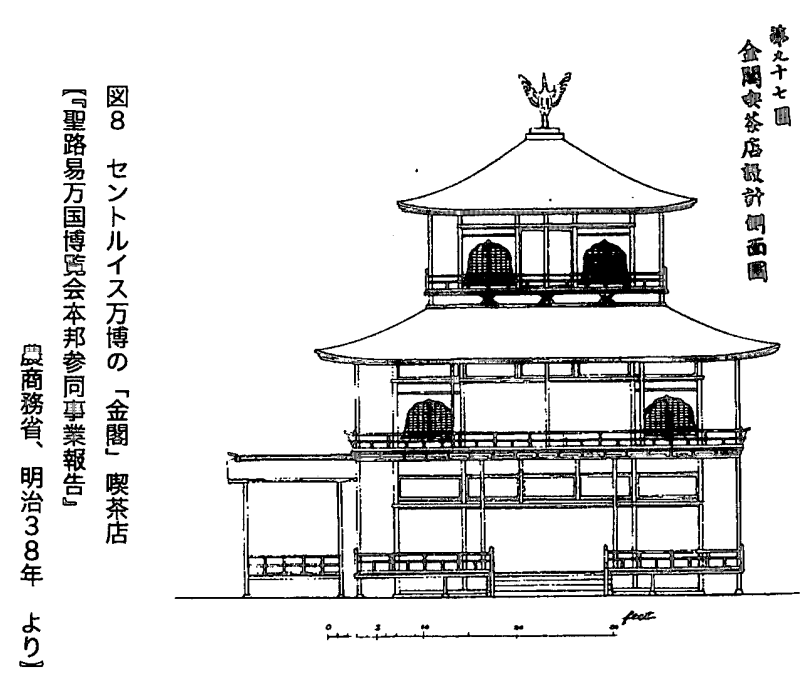


日本館と同様に日本政府敷地内に建てられたものであり、それなり に本格的な造形がなされた物で、3 層構成を採っていること、最上 層が下 2 層よりも小さい点など、形態的にはパナマ万博の日本館よ りもモデルに似て見える。

そして、パナマ万博の日本館となるが、このようにモデルとして 3 度も登場する建物は他に見あたらない。このことから、当時の日 本人 (建築家)の意識の中に、金閣の造形が「日本建築」を代表し、 その美を（少なくとも外国に対しては）訴えることのできる建物で あると認識されていた事を窥うことができる。

\section{6. 模式の混在についての考察}

\section{6-1.混在の背景・動機}

この日本館では、モデルとなった金閣とは時代の異なる鎌倉末期 から豊臣初期の意匠が用いられていたが、このような様式の混在は 以前の日本館にも既に見ることができたものであった。

実在の歴史的名建築をモデルとした日本館の噶矢は、明治 26 年 のシカゴ万博での日本館であるが、それにも様式の混在があった 23)。この建物は前述のように平等院鳳凰堂をモデルに採つたもので、 「鳳凰殿」と名付けられた。その建設目的は「日本建築」固有の美 を表現するとともに、平安中期、室町時代、江戸時代の 3 時代の美 術品を展示することにあった。その結果、鳳凰殿は 3 棟の建物から なり、全体のモデルとは別に各々の棟が内部展示である各美術品の 時代様式を表現するよう、個々のモデルが求められたのである。す なわち、平安中期は全体のモデルと同様に平等院鳳凰堂とさらに京 都御所が、室町時代には銀閣寺が、江戸時代には江戸城が選ばれた。 しかし、それらの建物はモデルを忠実に復原したのではなく、3 棟 で一つの建物としての總まりをつけるために、異なる時代の意匠を 混在させたものであった。すなわち、混在の動機は直接的には建築 美の表現にあったのであるが、その大本は 3 時代の美術の表現とい う、内部展示との関連からもたらされたものであった。

1900 年パリ万博の日本館もモデルと異なる意匠の混在が見られ るものであった。その時の報告書 ${ }^{23)}$ では、意匠の混在があること 及びその理由が初めて記された。モデルとなったのは法隆寺金堂で あって、報告書に記されていた混在の理由とは、モデル通りでは形 態的に簡素過ぎ、また採光上も問題があったからとしているが、最 終的にはこの日本館の建設目的が一時代を表現することにあったの ではないから時代的に異なる意匠が混在していても問題ないとして いるのである。これに対して、報告書以外の史料からは、样式の混 在は、内部で行われた美術展示との関連や設計者が捉えていた建物 と展示内容との結びつきといった要因により引き起こされたことが わかっている ${ }^{25)}$ 。すなわち、設計者は建物が展示内容を表現する ものであると考えており、その展示内容は日本美術の歴史的変迕を 示そうというものであった。すなわち、ここでも建物内で行われる 展示内容が外観に影響し、様式の混在を招いたのである。

これらに対し、パナマ万博での日本館の主体は接待館, 事務室で あり、これまでの日本館に求められた美術展示については、これと は別に特別展示館が建てられた。接待館，事務室は展示物との関連 はないから、以前の日本館のような動機からモデルとは異なる時代 の意匠を混在させる必要性はなかった。

$6-2$. 混在に対する意識
ここで、それぞれの日本館の設計についての記録や記述などか ら、混在に関する箇所を引いてみると、その意識の差が明らかであ り、興味深い。

鳳凰殿の設計者である久留正道については 徳川幕府ノ建築二八高欄ハナイ足利氏モ高欄ハナイ并シナガラ藤原氏八 高欄ガアル夫デ稌倍ナク徳川足利ニモ高欄习附ケテ同栐ニ見へル様ニシ マシタ（略）

別々ニ建テルナラ鬼モ角三時代ノ物 ターツニスルノデアルカラ多少ノ違 ナケレバナラヌ、唯ダ戸ニ持ツ往ツテ横二條ノアルモノヨ十文字スル位

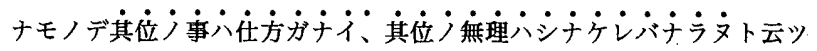
テ漸ク三時代ノ家ヨート總メニシタノデス ${ }^{26)}$ (傍点筆者)

と述べている。実はこの久留の言葉は、その講演会の質疑応答の場 で「3棟の建物を連続して建て、かつ 3 時代の建物を再現したとい うのに、様式(意匠)の違いはどうしたのか？」という問いが出さ れた故に答えたものなのであった。その結果、全体としての統一感 を得るために仕方なく様式の正確な再現をあさらめ、異なる時代意 匠を混在させたことを告白したというものであった。

1900 年パリ万博の日本館について、モデルにはない花頭㝕を用 いたことについて、その時の報告書では以下のように記されている。

蓋シ動鐘空八室町以後ノモノ二係り、法隆寺/建築卜ハ固ヨリ其ノ時代 ヨ異ニスルモ、本館八強テ一時代 ラサル 以テ便宜上之ヨ取リタルナリ ${ }^{27)}$ (傍点筆者)

ここでは、建物がモデルを持ちながらも、その特定の時代を無理に 表現するものではないからと断り、花頭空 (釣鐘空)を用いたこと を「便宜上」とするのである。ここからは、モデルに忠実でなかっ たことへの責めに対する防衛意識のようなものが感じられる。

これらとは对照的に、武田は以下のように述へている。 今回桑港万国大博覧会々場内に建てられたる日本政府館及び庭園は自分 としては我国従来の諸焃式を参配して新たなる要求及び指定されたる地 形に適応する様其最善を盡さんとせるものであつて決して彷来の歴茰的 建嫣物の㝍真でも文模字でもない、唯大體の概念を鹿苑寺金閣に取り細

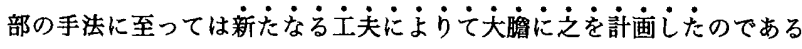
28) (傍点筆者)

「細部手法」の「新たなる工夫」とは鎌倉末期から豊臣初期にかけ ての意匠を組み込んだことを指すと考えられるから、それを使って 大胆に計画したというのである。モデルと異なる意匠を混在させる ことは、既に過去の日本館で見られるものであるから、本来「新し い手法」とは言えない。武田がその事実を知っていたか否かは現在 確認することはできないが、また、知った上での発言であるならよ り重要となるが、「新しい」と主張している点に、その手法に对す る彼の目的意識や自信が読みとれる。

さらに、武田が「歴史的建築物の写真でも模写でもない」とはっ きりと強く言い切っている点は、これまでの日本館でのモデルへの 忠実性に対する態度と全く対照的である。すなわち、これまでは意 匠の混在により忠夷な復原でないことを言い訳するが如く述べられ ていたのに対して、武田はむしろ忠実であることを恥じるが如く述 べているのである。すなわち、その設計行為がモデルとなった建筑 の美を忠実に再現することにあるのではなく、新たな美を生み出そ うという創造的なものであることを主張していると考光られる。 したがって、ここから読み取ることのできる武田の様式の混在 
に対する態度は、これまでに見ることのできなかった積極的なもの で、「積極的に折克を試みながら新しい和風建築をつくつてみせる という発想」 ${ }^{29)}$ が、ここに至って確立していることを確認できる。

\section{7.まと㐌}

パナマ万博の日本政府館が、鹿苑寺金閣という実在の歴史的日本 建築をモデルとした点は、シカゴ万博での鳳凰殿以来の前例に則つ たものと言える。と同時に、本万博以降の日本館には実在の名建築 をモデルとしたものは見られなくなる。また、モデルの時代は、中 心建物である接待館で鹿苑寺金閣という室町時代、特別陳列館も平 安時代であり、これはシカゴ万博でのモデル候補に挙げられた時代 と同じであり、この 2 時代の建築物の評価が相変わらず高いことを 示している。そして、モデルの报いや意匠の混在の目的からは、建 筑家が「新しい和風建築」を創り出すことをはっきりと意識する段 階へと到達していたことが明らかになった。こうしたことから、パ ナマ万博の日本館は、鳳凰殿以来続いた明治の万国博日本館の総決 算と言えるであろう。

武田五一の日本建築作品については、パナマ万博以降に播州清 水寺や円教寺摩尼殿などの社寺建築の大作を手がけた。それらは伝 統様式を畦守した保守的なものではなく、武田流の解积が施された 「新しい和風建築」と考えられるものである。すると、パナマ万博 の日本館は、基本的には社寺建築の形態を用いているから、武田流 の新しい社寺建築の先駆けとなる作品と考えられる。すなわち武田 は、万国博日本館という，仮設建築の設計という機会を捉えて「新 しい和風建築」を試し、その成果を踏まえ、播州清水寺をはじめと する「日本建築」作品を創造していったと言えるのではないか。 これより、パナマ万博の日本館は武田の作品としては、この後の武 田流の和風建築、特に社寺建築の雔形として評価されるべきものと 考える。

\section{既辞}

本稿をまとめるにあたって、神戸大学の足立裕司教授から資料の 提供や多大なる教示を賜った。記して謝意を表したい。

\section{野}

1）浜口隆一・山口広『万国博物語』鹿島出版会、昭和 41 年に上れば、 開催理由については 1907 年のサンフランシスコ大地震からの復興を記 念することもあったといわれる。

2) 黑川直樹「1915 年パナマ・太平洋万国博（サンフランシスコ）の日 本館について」『日本建築学会 2003 年度大会 (東海) 学惴講演梗概焦 $\mathrm{F}-2$ 』

3）藤岡洋保・深谷康生「戦前に海外で開かれた国際博覧会の日本館の和風 意匠について」『日本建築学会計画系論文報告集』1991.1

4) 『巴奈馬太平洋万国博筧会参同事務報告』兆商務省、大正 6 年

5）『報告㫪』第二編第一章第一節本邦政府参同決定二至リ夕ル迄/毫情

6)これに先立つ例としては、明治 37 年 (1904) のセントルイス万博がある。 そこでは、明治 35 年の参同決定值後に絪成された米国博覧会準備委員 会に久留正道、妻本頼黄、矢霞賢吉が委員されていた。さらに矢橋は今 回の武田と同様に現地に派息され、建築についての様々な調査を行い、 日本館についての展望を報告をしたが、矢橝の案は残念ながら各種の 事情により実現に至らなかった。（抽稿「1904年セントルイス万国博 における日本館について」『日本建築学会大会学術講演梗概集 F』1992 年を参照されたい。）その意味で、本稿で述べるパナマ万博で武田の活 動は、参同事業に建築家が最初から積極的に関わり、かつその展望を実 現させた最初の例とい方よう。
7) 『報告書』第二編第一章第二節参同事業ノ準備

8 )「特別館」の内容の一部として構想されていた、政府出品を陆列する目 的は後述する特別陳列館として実現した。日本政府館と特別陳列館の中 でも特に前者を中心建物と判断した理由には、「特別館」檴想の段階で 建設の第一の目的が「接待」にあったこと、『報告書』中での建物説明 に割かれた頁数及び揭載された写真数は日本政府館の方が多いこと、な どがある。さらに、武田五一は「パナマ太平洋万国博覧会所見」『建築 雑誌』342 号 (T4.6)で、「其建物の中で一番主となるべきものは政府接 待館と称するものであります」と述へている。

9) サンフランシスコの日系業者により出版された『巴奈馬太平洋万国大博 覧会写真蛅』青木大成堂(サソフランシスコ)、1915 年 の「日本政府酷地全景」 に载せられた武田による説明

10）接待館は池に面して建つが、特にその部分が金閣に似ているとしている。

11）報告書』第二嗝第五章第二節日本政府館及び正門 より。

12) 武田五一「パナマ太平洋万国博覧会所見 (大正 4 年 5 月 10 日通常講演)」 『建築雑誌』342号 (T4.6)

13) 註 11 に同じ

14) 註 11 に同じ。本城清右衛門、京都市下京区仏具屋通。なお、工事契約 は国内での切組、現場での組立それぞれ別であったが、いずれも本城が 請け負った。

15）『報告垫』第二編第五章第三節特別陳列館

16) 註 12 に同じ

17) 同上。

18）井上章一「日本館のエキゾキシズム」吉田光邦編『図説万国博覧会史 1851-1942』思文閣出版、1985 年

19）足立裕司「武田五一の建築観とその形成期について 武田五一研究。」 『日本建築学会計画系諭文報告集』S60.8。

20）いずれも博物館明治村編集『武田五一人と作品』名古屋鉄道株式会社、 昭和 62 年 所収の「年譄」より。

21) 註 19 に同じ。

22) 抽著「鳳凰殿の形態とその成立要因について」『日本建築学会計画系論 文報告集』1992.4

23) 同上。

24）『千九百年巴里万国博覧会臨時博覧会事務局報告』農商務省、明治 35 年

25) 批著「1900 年パリ万博における日本館の形態について」『日本建筑学 会計画系論文報告集』1993.8

26) 久留正道「米国博覧会へ出品/鳳凰殿二付テ」『工学会誌』M26.10

27) 註 20 に同じ

28) 墇 9 に同じ

29) 註 3 に同じ 